Jurnal Ilmu Sosial dan Pendidikan (JISIP)

Vol. 6, No. 1 Januari 2022

e-ISSN : 2656-6753, p-ISSN: 2598-9944

DOI: 10.36312/ jisip.v6i1.2695/http://ejournal.mandalanursa.org/index.php/JISIP/index

\title{
Perlindungan Hukum Pencipta Terhadap Download Music Streaming Dari Sebuah Platform Digital
}

\author{
Della Sarafina Hutagalung \\ Fakultas Hukum, Universitas Indonesia
}

\begin{tabular}{l}
\hline Article Info \\
\hline Article history: \\
Received 08 Desember 2021 \\
Publish 02 januari 2022 \\
\end{tabular}

Keywords:

Copyright,

Streaming Music,

Reproduction

\begin{abstract}
The rapid development of technology brings changes in all areas of life. This is marked by the creation of various digital platforms that make it easier for everyone to display their work. The works displayed on various digital platforms are the result of human ability and creativity that can create Intellectual Property Rights (hereinafter referred to as HKI). To respect and protect these creations, it is necessary to hold a form of protection through copyright. Normative legal research consists of research on legal principles by emphasizing on secondary data by studying and reviewing legal principles or principles, both in positive legal principles, cases and related national and international laws and regulations. with the main problem under study. The results of this study are in providing a protection for a work, especially to avoid duplication, granting permission in the use of copyrighted music and songs by users (users) is carried out with a license agreement accompanied by the payment of royalties to the
\end{abstract}

\begin{tabular}{l}
\hline Info Artikel \\
\hline Article history: \\
Diterima 08 Desember 2021 \\
Publis 02 januari 2022
\end{tabular}

creator.

\begin{tabular}{l}
\hline ABSTRAK \\
\hline Perkembangan teknologi yang pesat tersebut membawa perubahan di segala bidang \\
kehidupan. Hal ini ditandai dengan terciptanya berbagai platform digital yang \\
memudahkan setiap orang yang menampilkan karyanya. Karya-karya yang \\
ditampillkan dalam berbagai platform digital merupakan suatu hasil kemampuan \\
dan kreativitas manusia yang dapat menciptakan Hak Kekayaan Intelektual \\
(selanjutya disebut HKI). Untuk menghormati dan melindungi karya ciptaan \\
tersebut, perlu diadakannya sebuah bentuk perlindungan melalui hak cipta. \\
Penelitian hukum normatif terdiri dari penelitian terhadap asas-asas hukum dengan \\
menekankan pada data sekunder dengan mempelajari dan mengkaji asas-asas atau \\
prinsip-prinsip hukum, baik dalam kaidah hukum positif, kasus-kasus maupun \\
ketentuan-ketentuan perundang-undangan nasional dan internasional yang \\
berkaitan dengan pokok permasalahan yang diteliti. Hasil dari penelitian ini adalah \\
dalam memberikan suatu perlindungan terhadap suatu ciptaan khususnya untuk \\
menghindari adanya penggandaan, pemberian izin dalam penggunaan karya cipta \\
musik dan lagu oleh para pengguna (user) dilakukan dengan perjanjian lisensi \\
disertai dengan adanya pembyaaran royalti kepada pencipta.
\end{tabular}

This is an open access article under the Lisensi Creative Commons AtribusiBerbagiSerupa 4.0 Internasional

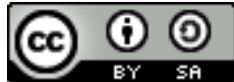

Corresponding Author:

Della Sarafina Hutagalung

Fakultas Hukum, Universitas Indonesia

Email: della.sarafina@ui.ac.id

\section{PENDAHULUAN}

Di era digitalisasi perkembangan teknologi, informasi dan komunikasi sangat pesat. Perkembangan teknologi yang pesat tersebut membawa perubahan di segala bidang kehidupan. Hal ini ditandai dengan terciptanya berbagai platform digital yang memudahkan setiap orang yang menampilkan karyanya. Musik dan lagu menjadi kebutuhan untuk mengekspresikan suasana hati 
dan emosi seseorang, dan dapat menjadi stimulus penambah semangat, dan menciptakan musik dan lagu dapat bermanfaat secara ekonomi. Tak heran jika suara lagu dan lirik yang diciptakan dipengaruhi oleh lingkungan pengarang, sehingga menghasilkan lantunan dan lirik yang merdu dan bermakna. Karya-karya yang ditampillkan dalam berbagai platform digital merupakan suatu hasil kemampuan dan kreativitas manusia yang dapat menciptakan Hak Kekayaan Intelektual (selanjutya disebut HKI).

Di era yang semakin maju ini, semakin banyak orang kreatif yang menciptakan ide-ide baru, lagu, di dunia seni. Menciptakan ide untuk orang dan kelompok yang kreatif dan brilian memiliki efek positif pada orang lain, seperti menciptakan kegembiraan, inspirasi, menghilangkan depresi dan ketegangan, dan meningkatkan perasaan emosional. Untuk menghormati dan melindungi karya ciptaan tersebut, perlu diadakannya sebuah bentuk perlindungan melalui hak cipta.

Di Indonesia, perlindungan terhadap hak cipta dituangkan dalam suatu pengaturan hukum yakni Undang Undang No. 28 Tahun 2014 tentang Hak Cipta (selanjutnya disebut UUHC). Hak cipta adalah hak ekslusif pencipta yang timbul secara otomatis berdasarkan prinsip deklaratif setelah suatu ciptaan diwujudkan dalam bentuk nyata tanpa mengurangi pembatasan sesuai dengan ketentuan peraturan perundang undangan.

Perkembangan dunia internet yang semakin maju membuat objek digital kini umum disebarkan, diperbanyak atau diperjualbelikan melalui media internet tersebut. Dalam hal ini kegiatan pengumuman, perbanyakan, penggandaan atau jual beli tersebut dilakukan dalam situssitus yang memang khusus dibuat untuk melakukan kegiatan sebagaimana tersebut serta telah memiliki pasarnya sendiri. Hal ini karena objek digital dianggap lebih praktis dan ekonomis ketimbang produk fisik yang membutuhkan perlakuan khusus seperti ruang penyimpanan, pengemasan dan pengiriman melalui kurir. Keuntungan lain dari perkembangan digital adalah ciptaan dapat dinikmati dan diakses dimanapun dan kapanpun. Pencipta atau pemegang hak cipta juga dapat memantau jumlah penggemar, bahkan dapat mengetahui persentase penggemar berdasarkan wilayah.

Dalam bidang musik, pecinta musik dapat menikmati musik melalui aplikasi streaming musik seperti YouTube, Spotify dan Joox. Platform ini membuat distribusi musik lebih mudah dan menjangkau lebih banyak pecinta musik. Namun, tidak seperti publikasi fisik, karya musik digital memiliki peningkatan risiko pembajakan. Dalam rilis fisik, pembajakan dan perekaman ulang masih dibatasi oleh masalah teknis seperti kualitas suara yang buruk dan resolusi gambar yang buruk seperti karya aslinya. Musik digital membuat pembajakan lebih mudah dengan kualitas suara dan kualitas gambar yang sama dengan aslinya. Keunggulan musik digital juga membawa tantangan baru dalam penghitungan lisensi musik dari platform digital.

Baru-baru ini telah banyak aplikasi layanan musik streaming yang dapat kita gunakan melalui smartphone sehingga kita dapat menikmati lagu dimanapun dan kapanpun, contohnya seperti Spotify, JOOX, dan lain sebagainya. Spotify adalah aplikasi modern yang menyediakan layanan streaming musik gratis. Kita dapat mengunduhnya secara gratis di Bursa Aplikasi. Melalui aplikasi Spotify, kita dapat mengakses daftar lagu, mencari lagu peringkat teratas, memutar secara acak lagi lagu yang direkomendasikan, menambah lagu favorit, dan juga dapat menikmati layanan hebat lainnya seperti memainkan lagu tersebut. Pada tahun 2005 untuk pertama kalinya ide tentang Spotify dikemukakan oleh pendirinya Daniel Ek dan Martin Lorentzon. Keduanya mengemukakan gagasan tentang layanan Spotify, sambil berbagi musik di antara mereka di sebuah apartemen di Swedia, dan meluncurkan versi beta kepada publik di tahun 2007Aplikasi resminya diluncurkan pertama kalinya pada tanggal 7 Oktober 2008. Spotify terus berkembang, dan sejak itu berekspansi di lebih dari 56 negara termasuk Amerika Serikat dan Filipina. Dalam perkembangannya kemudian, Spotify mendapatkan perjanjian kerjasama dengan Universal Music Group, Warner Music, EMI Group, Sony Music Entertainment, dan Merlin.

Berdasarkan data yang disebutkan oleh Center for Digital Society (CfDS) FISIPOL 
Universitas Gadjah Mada dalam laporannya memproyeksikan jumlah pengguna Spotify pada kuartal kedua tahun 2021 mencapai 165 pengguna. Hal ini memberi pengertian bahwa pengguna platform digital ini mengalami kenaikan yang sangat signifikan jika dibandingkan pada tahun sebelumnya sebanyak 130 juta pengguna dan pada tahun 2015 jumlah pengguna hanya menyentuh sebanyak 18 juta pengguna.

Dalam Undang-Undang Hak Cipta Nomor 28 Tahun 2014, royalti didefinisikan sebagai imbalan atas penggunaan hak manfaat atas ciptaan atau produk hak yang bersangkutan yang diterima oleh pencipta atau pemilik hak yang bersangkutan. Menteri Hukum dan Hak Asasi Manusia secara khusus mengatur besaran biaya perijinan untuk 26 lokasi/media seperti restoran, kafe, konser musik, pameran, bioskop, stasiun televisi, radio dan hotel. Namun, peraturan ini tidak termasuk biaya lisensi untuk platform digital. Platform musik digital seperti Youtube dan Spotify sebenarnya memiliki aturan sendiri untuk membayar royalti kepada penulis dan pemilik hak. Misalnya, Spotify memiliki dua jenis biaya lisensi. Pertama, biaya masuk yang timbul dari setiap lagu yang diputar di Spotify dan dibayarkan kepada artis melalui label rekaman atau distributor. Kedua, biaya penerbitan. Biaya lisensi dibayarkan kepada pencipta atau pencipta atas nama pengguna melalui lembaga pengelola hak (LMK) dan lembaga. Platform digital sudah memiliki mekanisme pembayaran loyalitas, tetapi sistem distribusi loyalitas musik digital menghadapi beberapa kendala karena tidak ada dasar hukum untuk mengatur platform digital.

Berdasarkan paparan latar belakang diatas, maka Penulis tertarik untuk menganalisis mengenai Perlindungan Hukum kepada Pencipta musik terhadap download musik dalam sebuah platform digital.

\section{METODE PENELITIAN}

Jenis penelitian dalam penelitian hukum ini adalah penelitian houkum normatif yaitu dilakukan dengan cara mengumpulkan dan menganalisis bahan pustaka yang didapatkan dari data primer dan data sekunder. Penelitian hukum normatif terdiri dari penelitian terhadap asas-asas hukum dengan menekankan pada data sekunder dengan mempelajari dan mengkaji asas-asas atau prinsip-prinsip hukum, baik dalam kaidah hukum positif, kasus-kasus maupun ketentuanketentuan perundang-undangan nasional dan internasional yang berkaitan dengan pokok permasalahan yang ditelit. Penulisan ini menggunakan jenis pendekatan peraturan perundangundnagan dengan cara mengkaji ketentuan yang ada di dalam Undang-undang Nomor 28 Tahun 2014 tentang Hak Cipta. Bahan hukum yang digunakan dalam penelitian ini yaitu bahan hokum primer dan bahan hokum sekunder. Bahan hukum primer yang digunakan adalah undang-Undang Nomor 28 tahun 2014 tentang hak cipta, sedangkan bahan hukum sekunder yang digunakan adalah literatur mengenai hak cipta. Pendekatan yang dilakukan dalam penelitian ini adalah pendekatan kualitatif sehingga muncul pemikiran atau teori yang kemudian dapat digunakan dalam proses penelitian.

Penelitian ini dilakukan dengan penelitian kepustakaan, yaitu pengumpulan data dilakukan melalui penelusuran terhadap bahan-bahan hukum primer berupa penelitian terhadap peraturan perundang-undangan nasional dan internasional. Bahan hukum sekunder yang meliputi berbagai macam literatur yang berkaitan dan relevan dengan penelitian ini yang berbentuk buku-buku, jurnal-jurnal, artikel-artikel, naskah akademik dan hasil penelitian dan bahan hukum tersier berupa makalah, surat kabar, kamus-kamus dan ensiklopedia. Sumber data yang digunakan dalam penelitian ini adalah dengan cara melakukan penelitian dokumen dan observasi. Teknik pengumpulan data yang digunakan selain meneliti secara langsung dokumen-dokumen yang berkaitan dengan topik yang diteliti, juga melakukan wawancara kepada pihak-pihak yang terkait tentang hal-hal yang berkaitan dengan masalah yang akan diteliti. Data-data yang terkumpul dianalisis dengan menggunakan metode analisis juridis kualitatif dan hasil analisis disajikan dengan menggunakan metode deskriptif analitis. 


\section{HASIL DAN PEMBAHASAN}

\subsection{Hak Cipta Lagu Dan Musik dalam Aplikasi Streaming Musik}

Musik merupakan salah satu hal yang tidak kalah penting yang mempengaruhihidup manusia. Di dalam Undang Undang Hak Cipta, hak terhadap musik atau lagu merupakan salah satu karya yang dilindungi sebagaimana dituangkan dalam Pasal 40 Undang Undang Hak Cipta. Hak cipta merupakan hak ekslusif bagi pemilik ciptaan untuk mengizinkan pihak lain menggunakan karya ciptanya, sebaliknya juga dapat melarang pihak lain untuk menggunakan karya ciptaannya. Dilarang menggunakan hak cipta tanpa persetujuan pemiliknya Hak Cipta. Menurut Bern Convention for the Protection of Literary and Artistic Works atau Konvensi Bern Tentang Perlindungan Karya-karya Literer (Karya Tulis) dan Artistik khususnya di dalam Pasal 2, yaitu : "The expression "literary and artistic works" shall include every production in the literary, scientificand artistic domain, whatever may be the mode or form of its expression, such as books, pamphlets andother writings; lectures, addresses, sermons and other works of the same nature; dramatic or dramatic musical works; choreographic works and entertainments in dumb show; musical compositions with or without words". Menurut pasal tersebut, hak cipta diberikan untuk lagu, lagu dengan kata, dan lagu tanpa kata, musik dengan kata-kata dengan lirik pada dan musik tanpa kata-kata tanpa lirik.

Terdapat 2 (dua) hak yang melekat dalam sebuah musik atau lagu yakni Hak ekonomi dan Hak Moral. Hak ekonomi adalah hak khusus bagi pencipta untuk mengumumkan atau memperbanyak ciptaannya dan memberikan ijin untuk itu.6 Hak demikian juga disebutkan dalam Pasal 2 Undang Undang nomor 19 Tahun 2002 dimana pada prinsipnya hak cipta merupakan hak ekslusif pencipta atau pemegang hak cipta untuk mengumunkan atau memperbanyak ciptaannya, yang timbul secara otomatis setelah ciptaan itu dilahirkan tanpa mengurangi pembatasan menurut aturan yang berlaku. Pencipta dan Pemegang Hak Cipta sebagaimana yang dimaksud dalam Pasal 9 Undang Undang Nomor 28 Tahun 2014 tentang Hak Cipta, memiliki Hak Ekonomi untuk melakukan : “(1) Penerbitan Ciptaan; (2) Penggandaan Ciptaan dalam segala bentuk ; (3) Penerjemaha Ciptaan; (4) Pengadaptasian, pengaransemen, atau pentransformasian ciptaan; (5) Pendistribusian Ciptaan atau salinannya; (6) Pertunjukan Ciptaan; (7) Pengumuman Ciptaan; (8) Komunikasi Ciptaan; (9) Penyewaan Ciptaan.

Hak moral adalah hak yang melekat pada diri pencipta atau pelaku yang tidak dapat dihilangkan atau dihapus tanpa alasan apapun walaupun hak cipta tersebut telah dialihkan. dalam Pasal 6 Konvensi Bern menyatakan terhadap hak moral pencipta memiliki hak untuk mengklaim kepemilikan atas karyanya dan mengajukan keberatan atas distorsi, mutulasi atau perubahan serta perbuatan pelanggaran lain yang berkaitan dengan karya tersebut yang dapat merugikan kehormatan atau reputasi si Pengarang atau Pencipta. Selain itu, dalam Undang Undang Hak Cipta sebagaimana disebutkan dalam Pasal 24 Hak Moral pencipta dari suatu karya cipta memiliki hak untuk :

a. Dicantumkan nama atau nama samarannya dalam ciptaannya ataupun salinannya dalam hubungan dengan penggunaan secara umum.

b. Mencegah bentuk distorsi, mutilasi atau bentuk pemotongan, perusakan, penggantian yang berhubungan dengan karya cipta yang pada akhirnya akan merusak apresiasi dan reputasi pencipta.

\subsection{Pembayaran Royalti Lagu dan Musik terhadap Streaming Musik dalam sebuah Platform Digital}

Dalam Undang-Undang Nomor 28 Tahun 2014 Hak Cipta merupakan hak khusus bagi Pencipta atau Pemegang Hak Cipta untuk memperbanyak atau menggandakan dan untuk mengumumkan hasil karya ciptaannya yang tumbuh bersamaan dengan lahirnya suatu ciptaan. 
Pencipta berhak pula atas manfaat ekonomi yang lahir dari ciptaanya tersebut. Manfaat ekonomi tersebut dapat bersumber dari kegiatan mengumumkan (performing right), kegiatan menyiarkan (broadcasting right), kegiatan memperbanyak yang mana termasuk didalamnya; mechanical, printing, syncronization, advertising, dan kegiatan menyebarkan (distribution right).

Sebagai konsekuensi musik dan lagu merupakan ciptaan yang merupakan hak ekslusif maka setiap orang/ badan usaha yang menggunakan karya cipta lagu dan/atau untuk suatu kegiatan komersil harus meminta izin terlebih dahulu kepada penciptanya dan atau kepada pemegang hak ciptanya yang oleh pencipta diberi kuasa untuk itu. Dengan kata lain, untuk memanfaatkan hak ekonomi pencipta tersebut, harus minta izin dari pencipta atau pemegang hak cipta yang sah.

Di era modern ini kita bisa mendengarkan lagu dimanapun dan kapanpun kita mau, karena sekarang sudah ada teknologi yang bernama streaming. Streaming adalah transmisi data dalam bentuk konten video atau audio ke perangkat elektronik seperti komputer atau ponsel melalui Internet . Ada perbedaan mendasar antara streaming dan mengunduh, hingga . Mengunduh adalah tindakan mengirim seluruh file audio dari satu komputer ke komputer lain melalui Internet. File audio yang diunduh disimpan dalam memori komputer dan dapat dikirim ke komputer lain, file audio juga dapat diedit atau diubah menggunakan perangkat lunak di komputer. Selama tahun 1980-an dan 1990-an, mengunduh adalah satu-satunya pilihan untuk streaming musik melalui internet, karena teknologi lain seperti streaming belum ditemukan. Aktif streaming, pengguna mempunyai alternatif untuk dapat menonton langsung tayangan streaming (live) dan layanan untuk ditonton nanti (delay) dengan cara mengunduh file tersebut terlebih dahulu. Pada ranah audio streaming, aplikasiaplikasi yang paling banyak dikenal adalah Spotify, Google Play Music, Apple Music, Amazon Music, Vevo, SoundCloud, JOOX dan lain-lain.

Kemudahan kemudahan pengunduhan musik melalui media internet seringkali menyebabkan hak hak pencipta menjadi terabaikan dan disalahgunakan. Maraknya penggadaan musik di Indonesia tidak terlepas dari banyaknya tersedia kemudahan dari karya tersebut diduplikasi. Penggandaan musik yang tidak resmi mengakibatkan kerugian bagi pencipta musik khususnya dalam bidang ekonomi karena telah hilangnya kompensasi ekonomi terhadap ciptaanya.

Dalam memberikan suatu perlindungan terhadap suatu ciptaan khususnya untuk menghindari adanya penggandaan, pemberian izin dalam penggunaan karya cipta musik dan lagu oleh para pengguna (user) dilakukan dengan perjanjian lisensi. Lisensi itu sendiri adalah izin yang diberikan oleh pemegang hak cipta (musik) kepada pihak lain untuk melaksanakan hak ekonomi atas ciptaanya syarat tertentu. Lisensi pengumuman musik diberikan berdasarkan surat perjanjian lisensi disertai kewajiban pembayaran royalty kepada pemegang hak cipta serta mempunyai akibat hukum terhadap pihak ketiga. Perjanjian Lisensi sebagai perjanjian tertulis pengalihan Hak Cipta, bukan hanya berdasarkan Undang-Undang No. 28 Tahun 2014 tentang Hak Cipta saja melainkan juga harus berdasarkan ketentuan-ketentuan mengenai syarat-syarat sah nya suatu perjanjian sesuai yang di atur dalam Pasal 1320 KUHPerdata.

Royalti adalah bagian dari produk atau laba yang diterima oleh pemilik hak cipta yang memberi ijin pihak lain untuk emnggunakan hak ciptaannya. Jumlah royalty yang wajib dibayar kepada pemegang hak cipta musik oleh penerima lisensi sesuai undang-undang berdasarkan kelaziman dalam praktik yang berlaku dengan memenuhi unsur keadilan. Undang Undang Hak Cipta tidak memberikan definisi mengenai royalti namun pada Pasal 45 ayat (3) mengatur tentang kewajiban pemberian royalti kepada pemegang hak cipta oleh penerima lisesnsi dan ayat (4) mengatur besarnya atau jumlah royalti yang wajib dibayarkan kepada pemegang hak cipta oleh penerima lisensi berdasarkan kesepakatan kedua belah pihak. Dengan 
adanya lisensi dan pembayaran royalti maka diharapkan ciptaan dapat dimanfaatkan demi kemajuan pengembangan usaha pada saat pemilik atau pemegang hak cipta tidak aktif memanfaatkan ciptaaanya.

Platform streaming musik Spotify menyatakan bahwa dalam membayar royalti artis tidak sesuai dengan per-play atau per-stream rate. Pembayaranroyalti yang diterima artis dapat bervariasi sesuai perjanjian yang mereka miliki dengan label atau distributor. Namun, pada dasarnya Spotify membayarkan 2 jenis royalti atas suatu lagu, yakni:

a. Royalti rekaman (recording royalties) yakni uang yang harus dibayarkan kepada pemegang hak cipta untuk rekaman yang di-streaming di Spotify. Pendapatan ini dibayarkan kepada artis melalui pemberi lisensi yang mengirimkan musik, biasanya label rekaman atau distributor mereka.

b. Royalti penerbit (publishing royalties) yakni uang yang harus dibayarkan kepada penulis lagu atau pemilik komposisi. Pembayaran ini dikeluarkan untuk penerbit,masyarakat pengumpul, dan agen mekanik berdasarkan wilayah penggunaan.

Disamping itu, Pelanggaran hak cipta sering terjadi di Indonesia, bahkan tindakantindakan melanggar tersebut seakan sudah dianggap sebagai suatu yang lumrah. Hal ini dikarenakan rendahnya pengetahuan masyarakat akan hak cipta dan kurangnya sosialisasi serta penegakan hukum atas pelanggaran-pelanggaran yang terjadi. Pencipta atau pemegang hak cipta berhak untuk memperjuangkan haknya, khususnya apabila terjadi pelanggaran atas ciptaannya. Pencipta atau pemegang hak cipta perlu mengetahui bahwa terdapat tiga bentuk sengketa terkait hak cipta, yakni perbuatan melawan hukum, perjanjian lisensi, dan sengketa mengenai tarif dalam penarikan imbalan atau royalti. Setelah mengetahui bentuk sengketa, pencipta atau pemegang hak cipta dapat menentukan apakah permasalahan tersebut ingin diselesaikan secara damai melalui alternatif penyelesaian sengketa (jalur mediasi, negosiasi, atau konsiliasi), melalui arbitrase, atau melalui pengadilan yakni Pengadilan Niaga.

\section{KESIMPULAN}

Perkembangan teknologi yang pesat tersebut membawa perubahan di segala bidang kehidupan. Hal ini ditandai dengan terciptanya berbagai platform digital yang memudahkan setiap orang yang menampilkan karyanya. Karya-karya yang ditampillkan dalam berbagai platform digital merupakan suatu hasil kemampuan dan kreativitas manusia yang dapat menciptakan Hak Kekayaan Intelektual (selanjutya disebut HKI). Untuk menghormati dan melindungi karya ciptaan tersebut, perlu diadakannya sebuah bentuk perlindungan melalui hak cipta.

Dalam memberikan suatu perlindungan terhadap suatu ciptaan khususnya untuk menghindari adanya penggandaan, pemberian izin dalam penggunaan karya cipta musik dan lagu oleh para pengguna (user) dilakukan dengan perjanjian lisensi. Lisensi itu sendiri adalah izin yang diberikan oleh pemegang hak cipta (musik) kepada pihak lain untuk melaksanakan hak ekonomi atas ciptaanya syarat tertentu. Lisensi pengumuman musik diberikan berdasarkan surat perjanjian lisensi disertai kewajiban pembayaran royalti kepada pemegang hak cipta. Terhadap akibat hukum tidak dijalankannya pembayaran royalti atau hal hal terkait pelanggaran hak, pencipta atau pemegang hak cipta dapat menentukan apakah permasalahan tersebut ingin diselesaikan secara damai melalui alternatif penyelesaian sengketa (non litigasi) atau melalui Pengadilan atau (litigasi).

\section{Saran}

Di era digitalisasi perkembangan teknologi, informasi dan komunikasi sangat pesat. Perkembangan teknologi yang pesat tersebut membawa perubahan di segala bidang kehidupan. Adapun saran yang dapat disesuaikan dengan perkembangan pada masa kini untuk memberikan perlindungan terhadap suatu hasil karya ciptaan terutama dalam bidang musik adalah penyesuaian 
regulasi terkait dimana semakin diaturnya secara rinci mengenai hak cipta terutama dalam bidang musik.

\section{Ucapan Terimakasih}

Dalam penulisan artikel ini Penulis mengucapkan terimakasih kepada Tuhan yang Maha Esa atas berkat dan rahmatnya Penulis dapat menyelesaikan artikel ini. Penulis juga menyampaikan terimakasih kepada orangtua, dosen, dan sahabat yang terus memberikan dukungan dalam penulisan artikel ini.

Penulis menyadari bahwa masih terdapat banyak kekurangan secara materi maupun hal lainnya dalam tugas akhir ini. Oleh karena itu, Penulis mengharapkan kritik dan saran yang dapat membangun Penulis. Adapun besar harapan penulis, tugas akhir ini dapat bermanfaat untuk civitas akademika dan masyarakat secara umum. Akhir kata, semoga Tuhan yang Maha Esa membalas kebaikan semua pihak yang telah membantu Penulis, dan senantiasa melimpahkan restu dan rezeki-Nya kepada kita.

\section{DAFTAR PUSTAKA}

Adisumato, Harson. (1995). Hak Milik INtelektual Khususnya Hak Cipta, cet.2. Jakarta : Akademika Prescindo,

Amiruddin dan Zainal Asikin, 2016, Pengantar Metode Penelitian Hukum, Cet. 9, Rajawali Pers, Jakarta, h.118.

Amiruddin dan Zainal Asikin. (2006). Pengantar Metode Penelitian Hukum, Cet. 9. Jakarta : Rajawali Pers/

Atmadja, Hendra Tanu. 2003. Hak Cipta Musik Atau Lagu. Jakarta : Fakultas Hukum Universitas Indonesia

Austerberry and David, The Technology of Video and Audio Streaming, (Burlington : Focal Press, 2005), hlm. 133

Austerberry and David. (2005). The Technology of Video and Audio Streaming. Burlington : Focal Press.

Berne Convention for The Protection of Literary and Artistic Works, Article 6

Crook, J., Tepper, F. A Brief History of Spotify.( 29 Juli 2015). diakses melalui https://techcrunch.com/gallery/a-brief-history-of-spotify/

Diakses melalui http://www.thembj.org/2014/05/spotifys-time/

Faisal Irfan. "Siasat Musisi Lokal Bertahan dari Jerat Spotify". (1 Desember 2020). Diakses

Faisal Irfani, "Siasat Musisi Lokal Bertahan dari Jerat Spotify", https://tirto.id/siasat-musisi-lokalbertahan- dari-jerat-spotify-giYA, diakses pada 1 Desember 2020

Harsono Adisumato, Hak Milik INtelektual Khususnya Hak Cipta, cet.2, (Jakarta : Akademika Prescindo, 1995), hlm. 7

Hendra Tanu Atmadja, 2003, Hak Cipta Musik Atau Lagu, Jakarta : Fakultas Hukum Universitas Indonesia, hal. 293.

Hendra Tanu Atmadja, Op.Cit, hlm 299

Hulman Panjaitan, Penggunaan Karya Cipta Musik dan Lagu Tanpa Izin dan Akibat Hukumnya, Jurnal Hukum Vol 1 No 2 (Agustus 2015), hlm. 116

Kiendl, W, Mei 2014, Spotify's Time. Music Business Journal (Berklee College of Music). TheMBJ.org.Diakses dari: http://www.thembj.org/2014/05/spotifys-time/, diakses pada tanggal 1 Desember 2020

Kiendl, W. Mei Spotify's Time. Music Business Journal (Berklee College of Music). (2014).

Lova, Putu Ayu Bertyna. Sistem Lisensi untuk Melindungi Hak Cipta Musik Indonesia. Diakses pada https://www.satuharapan.com/read-detail/read/sistem-lisensi-untuk-melindungi-hakcipta-musik-indonesi 
melalui https://tirto.id/siasat-musisi-lokal-bertahan-dari-jerat-spotify-giYA.

Panjaitan, Hulman. (2 Agustus 2015). Penggunaan Karya Cipta Musik dan Lagu Tanpa Izin dan Akibat Hukumnya. Jurnal Hukum Vol 1 No 2

Spotify, "What Type of Royalties Does Spotify Pay?". Diakses pada https://artists.spotify.com/faq/music\#royalties

Spotify, What Type of Royalties Does Spotify Pay?, https://artists.spotify.com/faq/music\#royalties Tamu Atmadja, Hak Cipta Musik atau Lagu, hlm. 289 